\title{
LYSURUS CRUCIATUS (PHALLACEAE, FUNGI), A PHALLOID SPECIES NEW TO THE HUNGARIAN BASIDIOMYCOTA
}

\author{
Csaba LocsmÁndi* ${ }^{1 *}$ and Gábor KovÁcs ${ }^{2}$ \\ ${ }^{1 *}$ Department of Botany, Hungarian Natural History Museum, \\ H-1087 Budapest, Könyves Kálmán krt.40, Hungary; locsmandi.csaba@nhmus.hu \\ ${ }^{2}$ Hortobágy National Park Directorate, H-4024 Debrecen, Sumen u. 2, Hungary
}

Locsmándi, Cs. \& Kovács, G. (2019): Lysurus cruciatus (Phallaceae, Fungi), a phalloid species new to the Hungarian Basidiomycota. - Studia bot. hung. 50(2): 347-356.

\begin{abstract}
Lysurus cruciatus is recorded as new to Hungary. Basidiomata of Lysurus cruciatus were detected in two localities of steppe grassland of Hortobágy, in years 2014, 2015 and 2017. Field observation, macro- and micromorphological description and taxonomic discussion of Lysurus cruciatus and a key of the stinkhorn species (Phallales) detected in Hungary are provided.
\end{abstract}

Key words: Basidiomycota, Hungary, new occurrence, Phallaceae

\section{INTRODUCTION}

Phallales E. Fisch. (Basidiomycota) includes the mostly colourful and fascinating gasteroid fungi (commonly named as stinkhorns) in appearance, highly specialized in spore distribution. Basidiomata begin to develop as initially hypogeous later semihypogeous, soft, inodorous (even if cross-sectioned) puffball-like "eggs" covered with a double-layered, inner gelatinous peridium which forms a basal volva at maturity. With exception of the representatives of some sequestrate (truffle-like) genera, which remain in egg stage at development (Claustula, Gastrosporium, Gelopellis, and Protubera), mature basidiomata appear as branched or unbranched stalk bearing slimy or sticky, putrid spore mass (gleba) on their tips. Spore mass is disseminated by arthropods, especially by insects. Spores simply stick to their feet or pass through their digestive tracks (TUNO 1998, CHEN et al. 2014).

\section{Ecology and geographical distribution of Lysurus cruciatus}

Lysurus cruciatus (Lepr. et Mont.) Henn. is a terricolous, saprobic species, widely distributed in tropical and subtropical areas, known from America, Asia, Australia, and Africa. It is introduced in Europe. It has been sporadically observed and detected in several European countries (KREISEL 2001): Bulgaria 
(Assyov \& Gashtarov 2007), Czech Republic, France, Great Britain, Germany, Ireland, Italy, the Netherlands, Norway, Russia, Spain, Sweden. It grows solitary or in groups or clusters in cultivated and uncultivated soils, on plant debris, also in greenhouses in temperate regions. According to Kreisel, the fructification of Lysurus cruciatus is "unstable in temperate or in Mediterranean climate" (KREISEL 2001).

\section{Observations in the field}

All basidiomata of Lysurus cruciatus were observed in the steppe grassland of the Hortobágy National Park. For the first time, two basidiomata (one young specimen in egg form and another over-mature, strong-smelling specimen) were found on a loess steppe patch embedded in Artemisio-Festucetum pseudovinae community on 24 November, 2014, in the northeastern part of "Borzas-puszta". The site was partially covered with some year old, decaying hay. Almost a year later, on 11 and 17 November, 2015, in the same location (Fig. 1) some young and old basidiomata of the same species appeared (Figs 2-3).

Despite the heavy rains in October and November in the next year, no basidiomata were found then. Until then, all the field observations were exclusively carried out by Gábor Kovács, retired conservation ranger of the Hortobágy National Park. From 2017, Csaba Locsmándi and Gizella Vasas specialised on taxonomy of

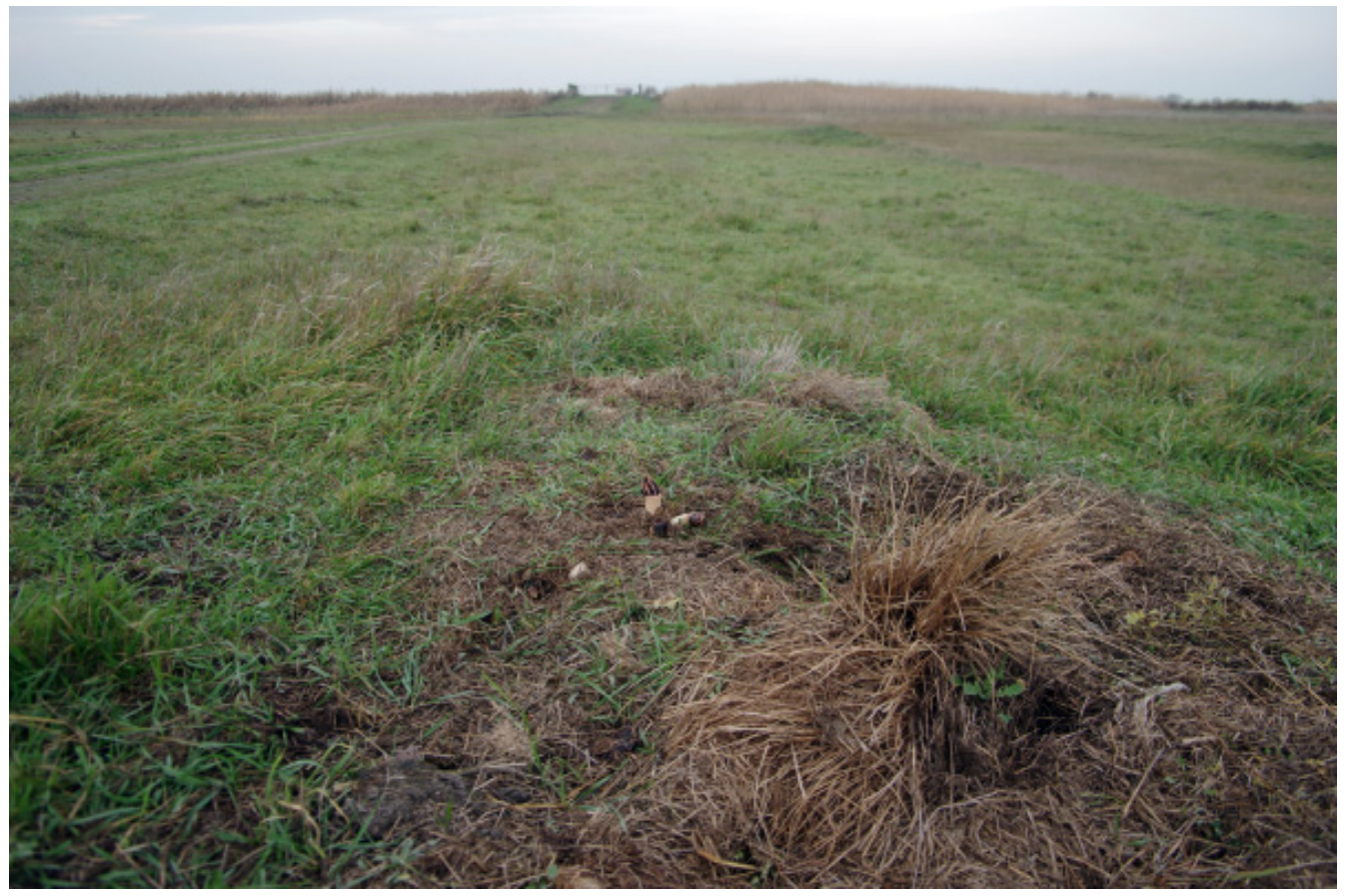

Fig. 1. Fruiting patch of Lysurus cruciatus at Borzas-puszta, 17.11.2015 (photo: G. Kovács). 


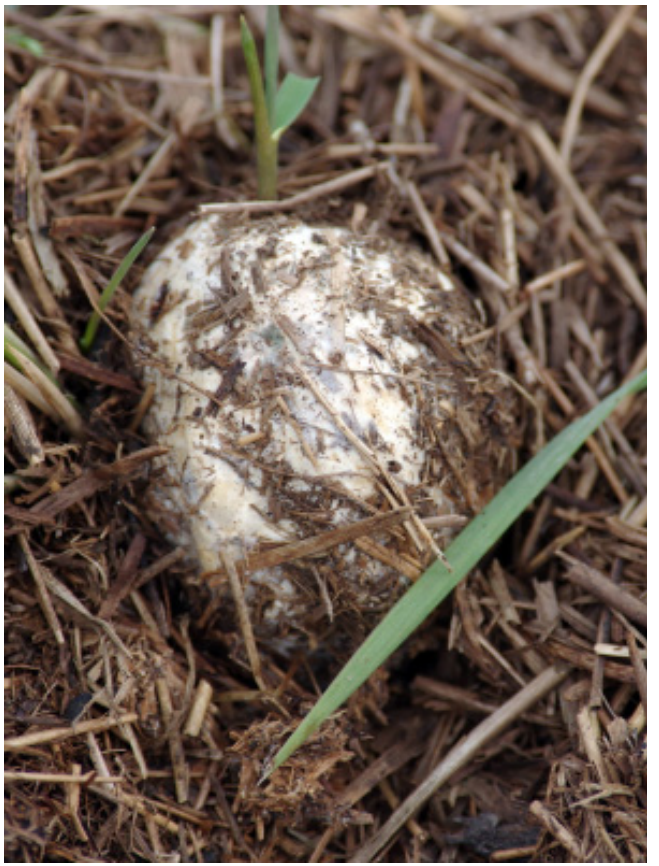

Fig. 2. Lysurus cruciatus in egg form, at the early stage of development (photo: G. Kovács).

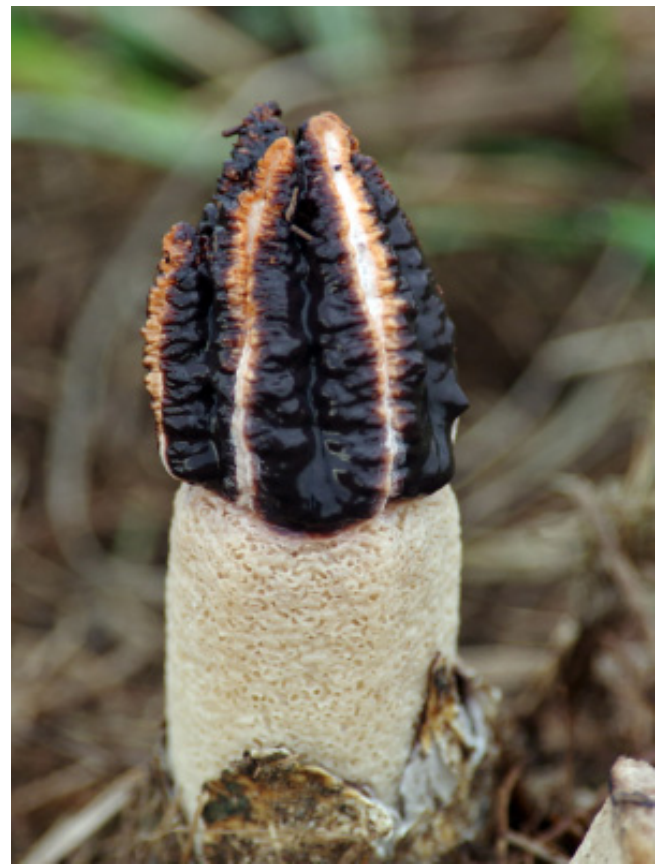

Fig. 3. Almost fully developed basidioma with sac-like volva and spore mass bearing relatively short apical arms (photo: G. Kovács).

Basidiomycota in the Hungarian Natural History Museum have also been involved in further field observations and investigations. They performed the exact macroand micromorphological identification of the species and proposed the Hungarian name "gyertyagomba" for Lysurus cruciatus. On 24 November, 2017, two emerging basidiomata and five eggs were observed in a new patch on highly decomposing horse manure at Máta village in Achilleo-Festucetum pseudovinae association (Fig. 4).

\section{Morphological description}

Immature basidioma ("egg") subhypogeous, completely encased in a peridium; soft, globose to subglobose, obovoid, up to $40 \mathrm{~mm}$ in diameter; with numerous mycelial cords attached to the soil. Peridium whitish, consisting of two layers, rupturing to form a basal, sac-like volva with irregular lobes. Outer layer whitish, thin, membranous; inner layer translucent, thick, gelatinous.

Mature basidioma epigeous, emerging from the "egg", composed of sterile pseudostipe and fertile apical arms. Pseudostipe 60-100 $\mathrm{mm}$ high, 10-25 mm wide, whitish or cream, cellular, minutely chambered, sponge-like in appearance, cylindrical, fragile, hollow in the centre, attenuated at the base, branching at the top to form 4-7 apical arms. Receptacle arms 10-30 $\mathrm{mm}$ high, 5-8 $\mathrm{mm}$ wide (size varies 


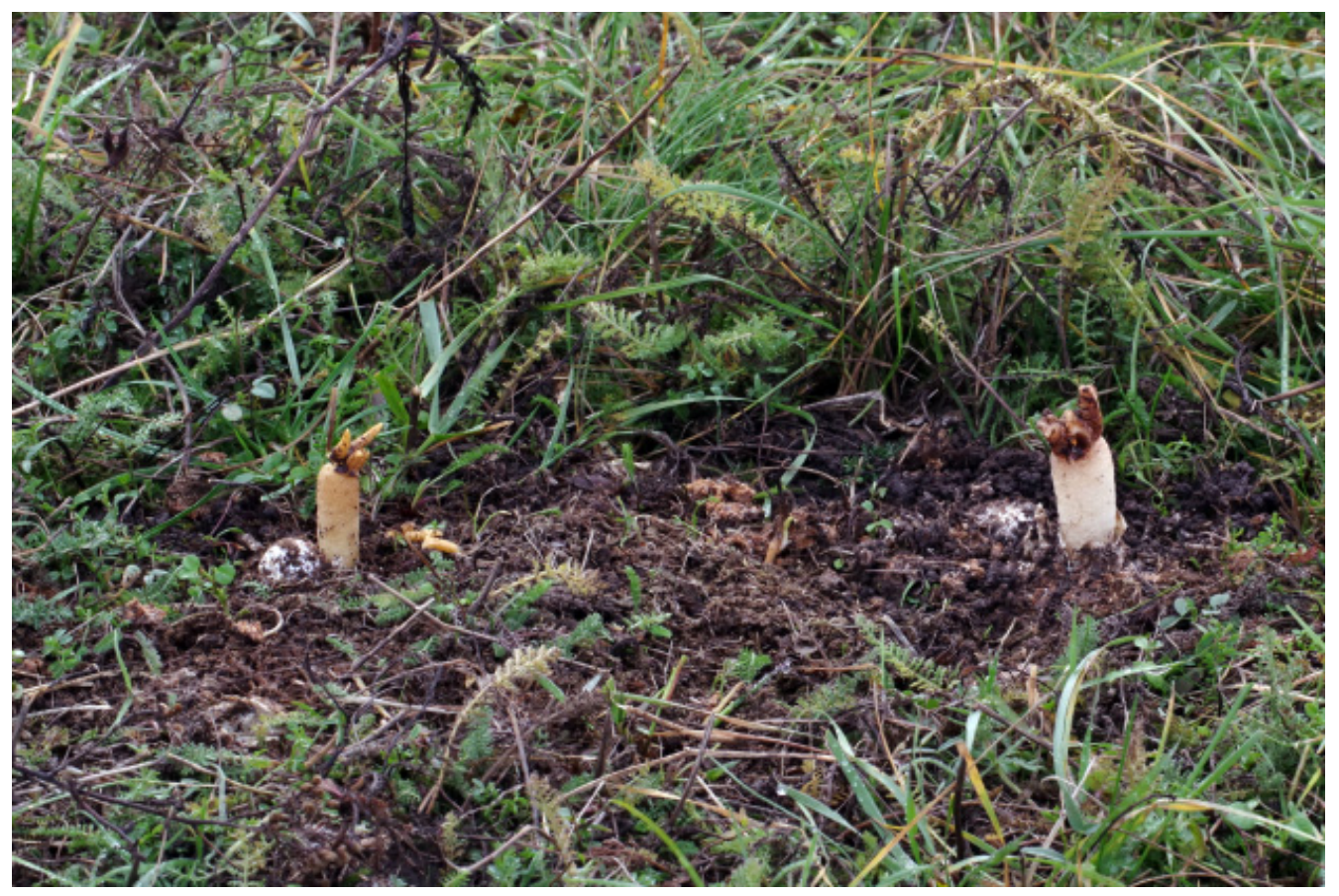

Fig. 4. Lysurus cruciatus basidiomata on highly decomposing horse manure at Máta village, in Achilleo-Festucetum pseudovinae association, 24.11.2017 (photo: G. Kovács).

within the same specimen), short and thick, three-sided, conical, hollow, incurved initially, slightly fused at their tips, but usually free with age and remaining more or less erect. Outer surfaces whitish, concave, more or less smooth, with a longitudinal groove. Inner surfaces convex, transversally wrinkled, covered with olive, olive-brown, mucilaginous, gradually deliquescing, spore slime or gleba. Mature gleba emits a fetid odour. Disgusting to people, but attractive to many species of insects, by whom spores dispersed and carried to other locations. Basidiospores 3-4 $\times 1-2 \mu \mathrm{m}$, hyaline, elliptic to oblong, thin-walled, smooth (Fig. 5).

Fungal cultures on $2 \%$ malt extract agar isolated from the egg stage of Lysurus cruciatus are white in colour, they form a dense substrate and aerial mycelia and show a relative slow radial growth ( $1 \mathrm{~mm} /$ day), respectively (Fig. 6). For long-term preservation of cultures, isolates were transferred to liquid nitrogen and deposited in the Fungal Genetic Resource Collection at the Hungarian Natural History Museum.

Material examined: Lysurus cruciatus, Hungary, Hortobágy National Park at Máta village, in Achilleo-Festucetum pseudovinae association, on highly decomposing horse manure. Date: 24.11.2017. Leg.: G. Kovács, Cs. Locsmándi \& G. Vasas. Det.: Cs. Locsmándi. Exsiccata reference number: 109749 BP. Fungal Genetic Resource Collection reference number: 3/07201. 


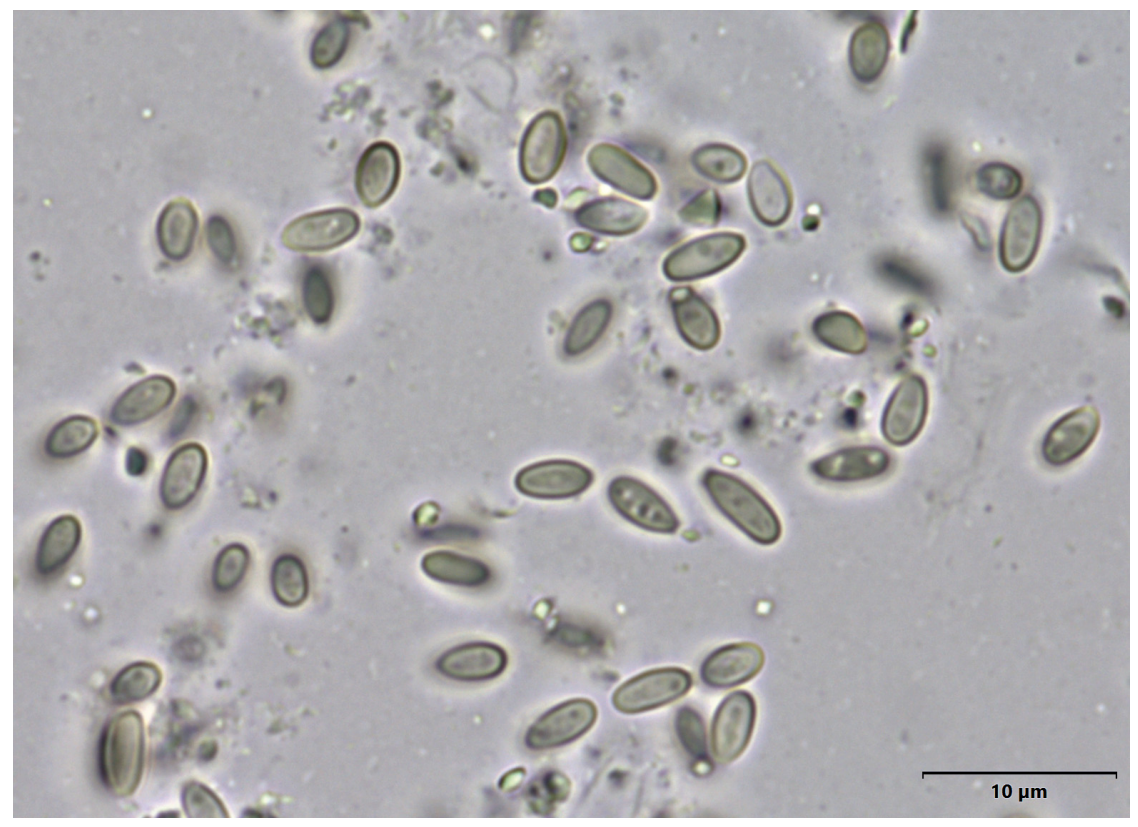

Fig. 5. Lysurus cruciatus spores. Scale bar $10 \mu \mathrm{m}$ (photo: Cs. Locsmándi).

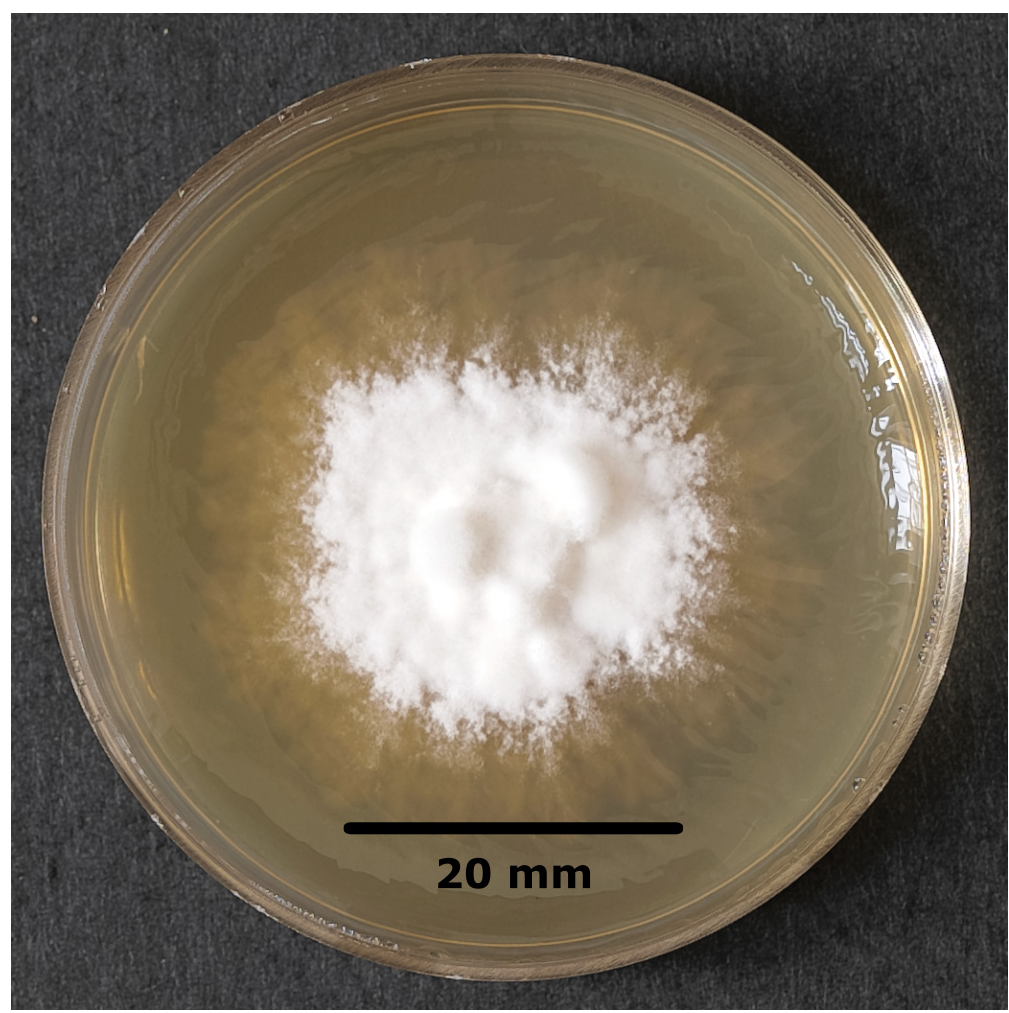

Fig. 6. Culture of Lysurus cruciatus. Scale bar $20 \mathrm{~mm}$ (photo: Cs. Locsmándi). 
Taxonomic discussion

The current genus name Lysurus was introduced by Elias Magnus Fries in Systema Mycologicum (FrIES 1823).

Facultative or heterotypic synonyms (MYcoвANK 2019b): Calathiscus Mont., Annales des Sciences Naturelles Botanique 16: 278 (1841); Dictyobole Atkinson, Botanical Gazette Crawfordsville 34: 42 (1902); Foetidaria A. St.-Hil., Annls Sci. Nat., Bot., sér. 2: 191 (1835); Kalchbrennera Berk., Gardeners' Chronicle 5: 785 (1876); Kupsura Lloyd, Mycological Writings 7 (Letter 73): 1303 (1924); Lloydia C. H. Chow, Bull. Fan Mem. Inst. Biol., Bot.: 27 (1935); Lysurus sect. Desmaturus Schltdl., Linnaea 31: 180 (1862); Lysurus sect. Schizmaturus Corda, Icones fungorum hucusque cognitorum 6: 22 (1854); Pharus Petch, Annals of the Royal Botanic Gardens Peradeniya 7 (1): 59 (1919).

Current type species of the genus is Lysurus mokusin (L.) Fr. (Fries 1823).

Lysurus cruciatus (Lepr. et Mont.) Henn., Hedwigia Beiblätter 41: 172 (1902)

Basionym: Aserophallus cruciatus Lepr. et Mont., Annales des Sciences Naturelles Botanique 4: 361 (1845).

Obligate or homotypic synonym (Мүсов ANк 2019b): Anthurus cruciatus (Lepr. et Mont.) E. Fisch. (1897).

Facultative or heterotypic synonyms (МYсов ANK 2019b): Anthurus borealis Burt, Memoirs of the Boston Society of Natural History 3: 504 (1894), Anthurus clarazianus Müll. Arg. (?), Anthurus sanctae-catharinae E. Fisch. (1897), Anthurus woodii MacOwan (?), Lysurus argentinus Speg., Anales de la Sociedad Científica Argentina 24: 68 (1887), Lysurus australiensis Cooke et Massee, Grevillea 18 (85): 6 (1889), Lysurus borealis var. klitzingii Henn., Hedwigia Beiblätter 41: 172 (1902), Lysurus borealis var. serotinus Peck, Bulletin of the New York State Museum 157: 49 (1912), Lysurus pusillus Coker, Mycologia 37 (6): 781 (1945), Lysurus tenuis F. M. Bailey, Contr. Fl. Queensland Fungi: 306 (1911), Lysurus texensis Ellis: 30 (1880), Mutinus sulcatus Cooke et Massee (1889).

Lysurus cruciatus was first described from French Guyana (capital Cayenne) in 1845 by François Mathias René Leprieur and Camille Montagne as Aserophallus cruciatus (Montagne 1845). Paul Christoph Hennings transferred it to the genus Lysurus in 1902 (HENNINGs 1902). Lysurus cruciatus is currently accepted by the relevant and searchable taxonomic online-databases, such as Index Fungorum (INDEX Fungorum 2019) and Mycobank (MycobANK 2019b).

Phallales contains species mainly of tropical or subtropical origin and is represented by seven families (Clathraceae, Claustulaceae, Gastroporiaceae, 
Lysuraceae, Phallaceae, Protophallaceae and Trappeaceae) supported by recent results of molecular studies (TRIERVEILER-PEREIRA et al. 2014). Lysuraceae is monotypic with only one immediately subordinate taxon Lysurus. At the present time, at least ten, generally accepted species belong to the genus (MYcoBANK 2019a): Lysurus arachnoideus (E. Fischer) Trierv.-Per. et Hosaka, L. brabmagirii C. Mohanan, L. corallocephalus Welw. et Curr., L. cruciatus (Lepr. et Mont.) Henn., L. gardneri Berk., L. habungianus G. Gogoi et V. Parkash, L. mokusin (L.) Fr. L. pakistanicus S. H. Iqbal, Kasuya, Khalid et Niazi, L. periphragmoides (Klotzsch) Dring, and Lysurus sphaerocephalum (Schltdl.) Hern. Caff., Urcelay, Hosaka et L. S. Domínguez (CAFFot et al. 2018).

Key to stinkhorn species (Phallales) occurring in Hungary (Red list categorisations are based on Rimóczi et al. 1999):

1a Basidiomata sequestrate, hypogeous, gleba not odorous, powdery at maturity Gastrosporium simplex Mattir.

Basidiomata hypogeous, often connected by a common rhizomorph, irregularly globose, subglobose, $0.5-2 \mathrm{~cm}$ across, encased in a peridium. Gleba whitish at first, then grey-ochre, finally powdery, not odorous. Spores finely verrucose, 3.5-5.2 × 3.5-4.5 $\mu \mathrm{m}$, hyaline or slightly ochre in colour. On sandy steppes near Festuca, Bromus, and Stipa tussocks. Rare and endangered species. Red list category: 2.

1b Basidiomata epigeous, only in egg-form, at the early stage of development subhypogeous, upper part covered with disgusting, fetid, slimy spore mass 2

2a Receptacle branching into tentacle-like arms ................................................ 3

$2 b \quad$ Receptacle unbranching .................................................................................. 4

3a Pseudostipe rudimentary, arms relatively long

Clathrus archeri (Berk.) Dring

Basidiomata subhypogeous at first, egg-like, up to $6 \mathrm{~cm}$ in diameter. The outer layer of peridium white, pinkish, inner layer gelatinous, translucent. Ruptured peridium forming a sac-like volva at the base of the pseudostipe. Receptacle arms 3-9 cm long, lattice-like, initially joined at their tips, soon opening outward. Inner surfaces of arms bright pinkish-red, coated with traces of dark olive-coloured, putrid spore mass. Spores $4-7.5 \times 2-2.5 \mu \mathrm{m}$, smooth, hyaline. This introduced species grows sporadically in deciduous and coniferous woods in Hungary. Red list category: 1.

3b Pseudostipe well-developed, arms relatively short Lysurus cruciatus (Lepr. et Mont.) Henn.

(see above). Red list category: not recorded yet. 
4a Spore bearing part is cap-or thimble-like, joining to the pseudostipe at the apex. Robust species ....................................................................................... 5

4b Spore bearing part conical, appearing as elongation of the pseudostipe. Receptacle entirely or partial red, pink or orange. Slender species ........... 6

5a Volva whitish Phallus impudicus L.

Eggs up to $6 \mathrm{~cm}$ across, with mycelial cord. The outer layer of peridium white, inner layer gelatinous, translucent. Volva sac-like, whitish. Receptacle up to $20 \mathrm{~cm}$ high. Pseudostipe whitish, hollow, fragile, sponge-like pitted, equal or tapering at both ends. Spore bearing part 3-6 cm broad, joining at the apex only, surface reticulate beneath the strong-smelling, olive-coloured spore slime. Spores 4-7.5 $\times 2-2.5 \mu \mathrm{m}$, smooth, hyaline. Widely distributed in deciduous and coniferous woods. Red list category: not listed as endangered.

5b Volva purplish

Phallus hadriani Vent.

Eggs up to $5 \mathrm{~cm}$ across, with mycelial cord. The outer layer of peridium purplish, inner layer gelatinous, translucent. Volva sac-like. Receptacle up to $15 \mathrm{~cm}$ high. Pseudostipe whitish, hollow, fragile, sponge-like pitted, equal or tapering at both ends. Spore bearing part $2-5 \mathrm{~cm}$ broad, joining at the apex only, surface reticulate beneath the fetid, olive-coloured spore slime. Spores 3-4 × 1.5-2 $\mu \mathrm{m}$, smooth, hyaline. Common on sandy soils, in woods especially in Robinieto or out of the woods, in gardens, parks. Red list category: 4.

6a Pseudostipe 5-10 cm high, more or less equal longitudinally, except for the abruptly narrowing tip. Spores $3-5 \times 1.5-2 \mu \mathrm{m}$

Mutinus caninus (Huds.) Fr.

Eggs up to $2 \mathrm{~cm}$ broad, with mycelial cord. Peridium white, occasionally with a pinkish tinge, with gelatinous translucent inner layer, rupturing to form a volva at the base. Receptacle up to $10 \mathrm{~cm}$ high. Pseudostipe more or less equal, at most as thick as a finger, orange to pink, paler or even white toward the base, hollow, fragile, spongy. Spore mass mucilaginous, deep olive or brownish olive, coating the upper $2-3 \mathrm{~cm}$ portion of receptacle. Odour disgusting but not as malodorous as Phallus species. Spores 3-5 $\times 1.5-2 \mu \mathrm{m}$, smooth, hyaline. Sporadically on ground and rotten wood, in deciduous and coniferous woods. Red list category: 3 .

6b Pseudostipe 9-17 $\mathrm{cm}$ high, from the middle, gradually tapering toward the tip. Spores 4-7 $\times 2-3 \mu \mathrm{m}$........................ Mutinus elegans (Mont.) E. Fisch.

Eggs up to $4 \mathrm{~cm}$ broad, with mycelial cord. Peridium white, occasionally with pinkish or roseate tinge. Receptacle up to $17 \mathrm{~cm}$ high. Pseudostipe finger-thick, thickest in the middle, gradually tapering toward the tip, orange to pink, paler with age and toward the base, hollow, fragile, spongy. Fetid spore mass mucilaginous, deep olive or brownish olive, coating the upper $2-6 \mathrm{~cm}$ portion of receptacle except for the very tip. Spores $4-7 \times 2-3 \mu \mathrm{m}$, smooth, hyaline. Very rare in Hungary, on the ground, and on rotten wood. Basidiomata take a long time to develop, up to two weeks. Red list category: 3. 
Acknowledgments - The authors wish to thank Gizella Vasas for her assistance in fieldwork and for her advice and suggestions in reviewing the manuscript.

Összefoglaló: Cikkünkben a gyertyagomba (Lysurus cruciatus) első magyarországi előfordulásairól számolunk be, a Hortobágyi Nemzeti Park területéről, ahol két termőfolton (Borzaspuszta, ill. Máta közelében), összesen három alkalommal (2014, 2015 és 2017) találtuk, kizárólag az őszi időszakban. Ezt a szömörcsögfélék (Phallaceae) rokonsági körébe tartozó szaprotróf fajt a 20. század elején hurcolták be Európába, trópusi és szubtrópusi területekről. Kontinensünkön ma is meglehetősen ritka, csak néhány előfordulási adatát ismerjük az európai országokból. A gyertyagomba viszonylag hosszú tönkje leginkább az erdei szömörcsögére (Phallus impudicus) hasonlít, azonban csúcsi termőrésze nem süveg, hanem rövid, szétváló karok formájában jelenik meg, amelyeket büzös gleba borít. Az undorítú szagú, nyálkás, bazidiospórákat tartalmazó glebát - a rokon fajokhoz hasonlóan - az ízeltlábúak, többnyire a rovarok terjesztik. A fajok közötti eligazodás megkönnyítése végett, a Phallales rendbe tartozó magyarországi gombafajokat határozókulcsba foglaltuk, és megadtuk rövid jellemzésüket is, veszélyeztetettségi besorolásukkal együtt. A 2017 novemberében gyüjtött fiatal termőtestekből fertőzésmentes izolátum is készült, amelyet hosszú távon, élő állapotban a Magyar Természettudományi Múzeum Gombagénbankjában, folyékony nitrogénben őrzünk.

\section{REFERENCES}

Assyov B \& Gashtarov V. (2007): Lysurus cruciatus (Phallales) - first record in Bulgaria and southeastern Europe. - Mycol. Balcan. 4: 93-94.

Caffot M. L., Hosaka K., Domínguez L. S. \& Urcelay C. (2018): Molecular and morphological data validate the new combination of Lysurus sphaerocephalum from Argentina, with some additional records on Phallales (Agaricomycetes). - Mycologia 110(2): 419-433. https://doi.org/10.1080/00275514.2018.1456834

Chen G., Zhang R.-R. \&. Sun W.-B. (2014): Spore dispersal of fetid Lysurus mokusin by feces of mycophagous Insects. - J. Chem. Ecol. 40: 893-899. https://doi.org/10.1007/s10886-014-0481-6

Fries E. M. (1823): Systema Mycologicum Vol. 2. - Officina Berlingiana, Lund, 620 pp.

Hennings P. (1902): Eine neue norddeutsche Phalloidee (Anthurus borealis Burt var. n. klitzingii P. Hennings). - Hedwigia Beiblätter 41: 169-174.

INDEX FUnGORUM (2019): Lysurus cruciatus (Lepr. et Mont.) Henn. - http://www.speciesfungorum.org/Names/SynSpecies.asp?RecordID=100531 [accessed on 13.10.2019]

KREISEL H. (2001): Checklist of the gasteral and secotioid Basidiomycetes of Europe, Africa, and the Middle East. - Österr. Z. Pilzk. 10: 213-313.

Montagne C. (1845): Cinquième Centurie de plantes cellulaires exotiques nouvelles. Décades VII à X. - Ann. Sci. Nat. Botanique 4: 346-367.

Mycoвank (2019a): Lysurus. - http://www.mycobank.org/Biolomics.aspx?Table=Mycobank\& Rec $=96195 \&$ Fields $=$ All [accessed on 13.10.2019]

MyсоваNк (2019b): Lysurus cruciatus. - http://www.mycobank.org/Biolomics.aspx? Table=Myc obank \&Rec $=122170 \&$ Fields $=$ All [accessed on 13.10.2019] 
Rimóczi I., Siller I., Vasas G., Albert L., Vetter J. \& Bratek Z. (1999): Magyarország nagygombáinak javasolt Vörös Listája. (Proposed red list of macrofungi in Hungary). - Mikol. Közlem., Clusiana 38: 107-129.

Trierveiler-Pereira L., Da Silveira R. M. B. \& Hosaka K. (2014): Multigene phylogeny of the Phallales (Phallomycetidae, Agaricomycetes) focusing on some previously unrepresented genera. - Mycologia 106: 904-911. https://doi.org/10.3852/13-188.

Tuno N. (1998): Spore dispersal of Dictyophora fungi (Phallaceae) by flies. - Ecol. Research 13: 7-15. https://doi.org/10.1046/j.1440-1703.1998.00241.x

(submitted: 13.10.2019, accepted 11.11.2019) 